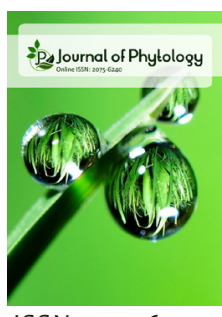

ISSN: $2075-6240$

\title{
Adjusting planting time of Binadhan-17 in boro season
}

\author{
Shampa Rani Ghosh', Sushan Chowhan ${ }^{2 *}$, Snigdha Roy³, \\ Dinesh Chandra Roy3, Md. Khan Jahan Ali4, Kamrun Nahar', \\ Md. Moshiur Rahman5, Md. Imdadul Hoque3, Majharul Islam ${ }^{6}$
}

'Entomology Division, Bangladesh Institute of Nuclear Agriculture, Mymensingh-2202, Bangladesh, ${ }^{2}$ Adaptive Research and Extension Division, Bangladesh Institute of Nuclear Agriculture, Sub-station, Ishurdi, Pabna-6620, Bangladesh, ${ }^{3}$ Plant Breeding Division, Bangladesh Institute of Nuclear Agriculture, Mymensingh-2202, Bangladesh, ${ }^{4}$ Plant Breeding Division, Bangladesh Institute of Nuclear Agriculture, Sub-station, Ishurdi, Pabna-6620, Bangladesh ${ }^{5}$ Plant Breeding Division, Bangladesh Institute of Nuclear Agriculture, Sub-station, Satkhira-9400, Bangladesh, ${ }^{6}$ Soil Science Division, Bangladesh Institute of Nuclear Agriculture, Mymensingh-2202, Bangladesh
Received: December 28, 2020 Revised: February 19, 2021 Accepted: February 22, 2021 Published: March 17, 2021

*Corresponding Author: Sushan Chowhan E-mail: sushano4@yahoo.com

\begin{abstract}
Boro rice (grown in winter under irrigated condition) contributes to the major portion of rice production (over $50 \%$ ) in Bangladesh. Binadhan-17 is a green super rice developed by BINA which requires $30 \%$ less nitrogenous fertilizer and water which is grown in aman season (primely produced under rainfed). Due to it's increasing popularity and adoption rice growers are keen to cultivate it in boro season also. Taking account of the above situation, two field trials were conducted at Magura during November 2019 to May 2020 to investigate the effect of variety, sowing dates and their interaction. Factorial RCBD (Randomized Complete Block Design) was applied for experimentation. Two rice varieties: Binadhan-17 $\left(\mathrm{V}_{1}\right)$, BRRI dhan58 $\left(\mathrm{V}_{2}\right)$ and three sowing times: $30^{\text {th }}$ November $\left(\mathrm{T}_{1}\right), 10^{\text {th }}$ December $\left(\mathrm{T}_{2}\right), 20^{\text {th }}$ December $\left(\mathrm{T}_{3}\right)$ were used as treatments. 35 days old seedlings were transplanted in main field. Relevant agronomic and morphological data were statistically analyzed through Statistix 10.0. Combined effect of the above factors at farm exposed that, $T_{1} \times V_{1}$ required longest days (159.33 days) to mature. but, comparatively short life cycle (149.97 days) was observed by $T_{3} \times V_{2}$. Maximum grain was yielded $\left(7.70 \mathrm{t} / \mathrm{ha}\right.$ ) by $\mathrm{T}_{2} \times \mathrm{V}_{1}$ and minimum $(5.74 \mathrm{t} / \mathrm{ha})$ by $\mathrm{T}_{1} \times \mathrm{V}_{1}$ treatment combination. Outcomes of on station revealed that, $T_{1} \times V_{1}$ needed more days (158.00 days) to mature; conversely, alike duration was noted with $T_{2} \times V_{2}$ (147.20 days) and $T_{3} \times V_{2}$ (145.43 days) which matured quite earlier. $T_{2} \times V_{1}$ produced the highest grain yield ( $7.41 \mathrm{t} / \mathrm{ha}$ ) and $\mathrm{T}_{1} \times \mathrm{V}_{2}$ the lowest (5.94 t/ha). Our results indicate that, planting of Binadhan-17 on $10^{\text {th }}$ December may give insect-disease free grains with optimum yield in context of Magura region. Farmers will be financially benefited if they cultivate this variety in the boro season in lieu of aman; due to higher yield.
\end{abstract}

KEYWORDS: Binadhan-17, boro, Magura, adjustment of sowing time, yield, planting time

\section{INTRODUCTION}

Three major rice seasons namely aus, aman and boro are the rice cultivating time in Bangladesh. All these constitute $100 \%$ of total rice production and grown in three overlapping seasons. Among them, boro rice (irrigated rice) occupies the second highest position, which is about $42 \%$ of total rice land and contributes over $55 \%$ of the total rice production. It has been persistently contributing to higher rice production in last successive years occurring in April-May (Bhowmik et al., 2012). Boro season of rice starts in November and ends in March (Chowhan et al., 2019). The environmental conditions i.e. lower respiration, evapotranspiration, temperature, less insect pest infestation, clear sunshine, congenial weather conditions etc. favors in getting higher rice yield during this time of the year. Total area under boro crop has been estimated 118, 32, 309 acres $(47,88,276$ hectares) in 2018-19 as compared to 120,07 , 983 acres $(48,59,367$ hectares) of the last year (2017-18). The harvested area has decreased by $1.46 \%$ this year (FAOSTAT, 2020). The main reason is, boro rice is totally dependent on supplemental irrigation which requires a huge amount of ground water thus farmers are trying to grow an alternative crop in the pattern which is water saving preferably pulse and oil seeds under zero tillage. National average yield (husked) of boro rice (including local, HYV and hybrid) during 2018-19 was 4.0851 $\mathrm{t} / \mathrm{ha}$. Whereas, mean national rice yield (milled equivalent) of Bangladesh was $3.16 \mathrm{t} / \mathrm{ha}$ during this period (BBS, 2019).

Binadhan-17 is a HYV (high yielding variety) of aman rice (grown by rainfed condition mostly); but as it's a photo

Copyright: $\odot$ The authors. This article is open access and licensed under the terms of the Creative Commons Attribution License (http://creativecommons.org/licenses/by/4.0/) which permits unrestricted, use, distribution and reproduction in any medium, or format for any purpose, even commercially provided the work is properly cited. Attribution - You must give appropriate credit, provide a link to the license, and indicate if changes were made. 
insensitive variety it can be cultivated in boro also. It needs $30 \%$ less water (irrigation) and urea fertilizer (BINA, 2017). Due to higher yield, finer grain quality, taste, higher market price and farmers preference it's being grown in dry season also. Time of sowing determines time of flowering and it has great influence on dry matter accumulation, seed set and seed yield (Sofield et al., 1977). Sowing at proper time allows sufficient growth and development of a crop to obtain a satisfactory yield because high temperature is one of the major environmental stresses that affect plant growth and development (Boyer, 1982). Contrary, variation in plating time is associated with disease and pest incidence also. To gain optimum yield and stability, it is necessary to take into consideration to determine the optimum sowing date for gaining potential yield of Binadhan-17 during boro season.

\section{MATERIALS AND METHODS}

This experiment was conducted during 27 November to 2019 to 23 May 2020 at the BINA substation Magura farm and farmer's field Sottopur, sadar, Magura. RCBD 2 factor design was followed for trial setup. Factor (A): Three sowing time viz. $30^{\text {th }}$ November $\left(\mathrm{T}_{1}\right), 10^{\text {th }}$ December $\left(\mathrm{T}_{2}\right), 20^{\text {th }}$ December $\left(\mathrm{T}_{3}\right)$ and Factor (B): Two variety: Binadhan-17 $\left(\mathrm{V}_{1}\right)$, BRRI dhan 58 $\left(\mathrm{V}_{2}\right)$. Seedlings were transplanted in the main field at 35 DAS (days after sowing). Unit plot size was $4 \mathrm{~m} \times 2.5 \mathrm{~m}$. All sorts of fertilizer were applied according to the instructions described at fertilizer recommendation guide by Ahmmed et al. (2018) for high yield goal. All sorts of pest and disease were controlled as per procedure described by, Paul et al. (2017) and Khatun et al. (2020)

Data on different growth and agronomic character were recorded from randomly 10 (ten) sampled hills when the crop retained 90\% maturity. For grain yield individual whole plot was harvested to calculate yield (t/ha) according to Chowhan et al. (2018). All the collected data were statistically separately analyzed by using ANOVA (analysis of variance) technique through Statistix 10 software (Statistix, 2020). Significance of mean difference was compared by LSD (least significant difference) test (Gomez \& Gomez, 1984) at $5 \%$ level of probability. A brief graphical status

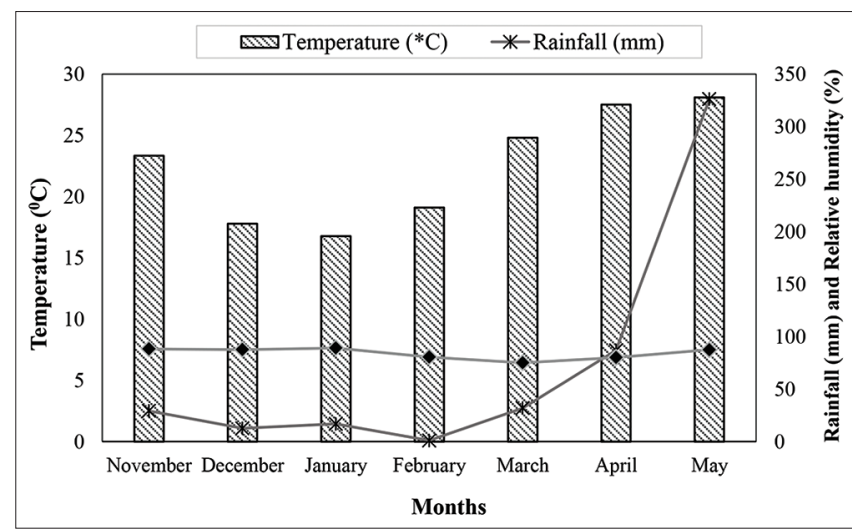

Figure 1: Weather data of the experimental period (November/2019 to May/2020) at Magura of the weather conditions during the experiment is presented in Figure 1 (BINA, 2019a).

\section{RESULTS}

Different growth and yield attributes of sowing time, variety and their interaction are shown in Table 1 and 2 . Their results and explanation are stated below sequentially-

\section{Plant Height}

In the on-farm trial significantly highest $(90.23 \mathrm{~cm})$ plant height was seen with treatment $T_{3}$. Sowing times $T_{1}\left(30^{\text {th }}\right.$ November $)$ and $\mathrm{T}_{2}\left(10^{\text {th }}\right.$ December $)$ gave statistically identical results (Table 1). At on-station, when seed was sown at $20^{\text {th }}$ December $\left(\mathrm{T}_{3}\right)$, then plant height was higher $(94.23 \mathrm{~cm})$ compared to other sowing dates. Sowing time $\mathrm{T}_{1}\left(30^{\text {th }}\right.$ November $)$ had the lowest height $(83.63 \mathrm{~cm})$ which was followed by $\mathrm{T}_{2}\left(10^{\text {th }}\right.$ December $)$.

Both in on-farm and on-station Binadhan-17 $\left(\mathrm{V}_{1}\right)(83.31 \mathrm{~cm}$ and $86.31 \mathrm{~cm}$ ) had the lower plant height than BRRI dhan 58 $\left(\mathrm{V}_{2}\right)(89.51 \mathrm{~cm}$ and $93.02 \mathrm{~cm})$.

Incase of interaction effect, treatment $T_{3} \times V_{2}$ showed foremost plant height both at on-farm and on-station $(94.33 \mathrm{~cm}$ and $98.33 \mathrm{~cm}) . \mathrm{T}_{2} \times \mathrm{V}_{1}$ beard the most dwarf height which was statistically same at on-farm and on-station $(80.60 \mathrm{~cm}$ and $88.20 \mathrm{~cm}) . \mathrm{T}_{1} \times \mathrm{V}_{2}$ also had the alike height (86.67) in the station trial.

\section{Number of Effective Tillers Per Hill}

Number of effective tillers per hill remained unchanged with the effect of sowing time, variety, and their interaction. Thus, it was non-significant.

\section{Panicle Length}

Length of panicle was non-significant at on-farm with the effect of sowing time and variety. But their combined effect resulted significantly highest panicle length by treatment $T_{2} \times V_{2}(23.87$ $\mathrm{cm})$ and lowest by $\mathrm{T}_{1} \times \mathrm{V}_{2}(21.80 \mathrm{~cm})$. In the station trial, longer panicle was observed with sowing time $\mathrm{T}_{3}(24.05 \mathrm{~cm})$ and shorter with $\mathrm{T}_{1}(21.73 \mathrm{~cm})$. Varietal effect was uninfluenced here. Interaction effect of sowing time and variety exhibited statistically identical and lengthier panicle with treatments $\mathrm{T}_{3} \times \mathrm{V}_{2}$ and $\mathrm{T}_{2} \times \mathrm{V}_{2}(24.87 \mathrm{~cm}$ and $23.73 \mathrm{~cm})$ contrary, shortest length was noticed in $\mathrm{T}_{1} \times \mathrm{V}_{2}(21.33 \mathrm{~cm})$.

\section{Days to Fifty Percent Flowering}

Both at on-farm and on-station sowing time $\mathrm{T}_{3}$ (118.67 days and 117.70 days) initiated early flowering and $T_{1}$ (125.67 days and 126.50) late flowering; whereas, with variety Binadhan-17 $\left(\mathrm{V}_{1}\right)$ beard late flowering (123.33 days and 123.89 days) than BRRI dhan58 $\left(\mathrm{V}_{2}\right)$ (121.33 days and 120.43 days) in both locations. Summative effect showed that, treatment $T_{3} \times V_{2}$ completed fifty percent flowering within the shortest time 
Ghosh et al.

Table 1: On-farm performance of boro rice varieties influenced by planting time, variety and their interaction

\begin{tabular}{|c|c|c|c|c|c|c|c|c|}
\hline Treatments & $\mathrm{PH}(\mathrm{cm})$ & NETPH & PL (cm) & DTFPF & NFGPP & NUGPP & TGW (g) & Duration (days) \\
\hline \multicolumn{9}{|l|}{ Sowing Time } \\
\hline $\mathrm{T}_{1}$ & $84.67 b$ & 8.83 & 22.47 & $125.67 \mathrm{a}$ & $151.87 \mathrm{a}$ & 20.07 & $24.51 \mathrm{a}$ & $157.00 \mathrm{a}$ \\
\hline $\mathrm{T}_{2}^{1}$ & $84.33 b$ & 12.17 & 22.97 & $122.67 b$ & $144.70 \mathrm{a}$ & 24.20 & $23.50 \mathrm{~b}$ & $154.38 \mathrm{ab}$ \\
\hline $\mathrm{T}_{3}^{2}$ & $90.23 \mathrm{a}$ & 10.83 & 22.93 & $118.67 \mathrm{C}$ & $114.47 \mathrm{~b}$ & 29.30 & $24.28 \mathrm{ab}$ & $152.32 \mathrm{~b}$ \\
\hline $\mathrm{LSD}_{0.05}$ & 3.51 & 3.38 & 1.10 & 0.91 & 20.04 & 9.98 & 0.86 & 2.81 \\
\hline Level of Significance & * & NS & NS & * & * & NS & $*$ & $*$ \\
\hline SEm & 1.57 & 1.52 & 0.50 & 0.41 & 8.99 & 4.48 & 0.39 & 1.26 \\
\hline \multicolumn{9}{|l|}{ Variety } \\
\hline$V_{1}$ & $83.31 \mathrm{~b}$ & 10.78 & 22.49 & $123.33 \mathrm{a}$ & $148.09 \mathrm{a}$ & $31.91 \mathrm{a}$ & 24.24 & $156.92 \mathrm{a}$ \\
\hline$v_{2}^{1}$ & $89.51 \mathrm{a}$ & 10.44 & 23.09 & $121.33 \mathrm{~b}$ & $125.93 b$ & $17.13 b$ & 23.95 & $152.21 \mathrm{~b}$ \\
\hline $\mathrm{LSD}_{0.05}$ & 2.86 & 2.76 & 0.90 & 0.74 & 16.37 & 8.15 & 0.71 & 2.29 \\
\hline Level of Significance & * & NS & NS & * & * & * & NS & * \\
\hline SEm & 1.28 & 1.23 & 0.40 & 0.33 & 7.34 & 3.66 & 0.32 & 1.03 \\
\hline \multicolumn{9}{|l|}{ Sowing Time $\times$ Variety } \\
\hline $\mathrm{T}_{1 \times} \mathrm{V}_{1}$ & $83.20 b c$ & $11.00 \mathrm{ab}$ & $23.13 a b c$ & $126.78 \mathrm{a}$ & $162.87 \mathrm{a}$ & $25.07 a b$ & $24.91 \mathrm{a}$ & $159.33 \mathrm{a}$ \\
\hline $\mathrm{T}_{1 \times} \mathrm{V}_{2}$ & $86.13 b$ & 6.67 b & $21.80 \mathrm{c}$ & $125.67 \mathrm{a}$ & $140.87 \mathrm{ab}$ & $15.07 \mathrm{~b}$ & $24.12 a b$ & $154.67 \mathrm{bc}$ \\
\hline $\mathrm{T}_{2 \times} \mathrm{V}_{1}$ & $80.60 \mathrm{c}$ & $11.67 \mathrm{a}$ & $22.07 b c$ & $124.82 \mathrm{a}$ & $159.47 \mathrm{a}$ & $34.67 \mathrm{a}$ & $23.80 a b$ & $156.77 \mathrm{ab}$ \\
\hline $\mathrm{T}_{2 \times}^{2 \times} \mathrm{V}_{2}^{1}$ & $88.07 \mathrm{~b}$ & $12.67 \mathrm{a}$ & $23.87 \mathrm{a}$ & $120.67 b$ & $129.93 \mathrm{bc}$ & $13.73 \mathrm{~b}$ & $23.20 \mathrm{~b}$ & $152.00 \mathrm{~cd}$ \\
\hline $\mathrm{T}_{3 \times} \mathrm{V}_{1}$ & $86.13 b$ & $9.67 \mathrm{ab}$ & $22.27 \mathrm{bc}$ & $119.67 \mathrm{~b}$ & $121.93 \mathrm{bc}$ & $36.00 \mathrm{a}$ & $24.02 a b$ & $155.59 \mathrm{bc}$ \\
\hline $\mathrm{T}_{3 \times} \mathrm{V}_{2}$ & $94.33 \mathrm{a}$ & $12.00 \mathrm{a}$ & $23.60 \mathrm{ab}$ & $117.66 \mathrm{c}$ & $107.00 \mathrm{C}$ & $22.60 \mathrm{ab}$ & $24.54 \mathrm{a}$ & $149.97 \mathrm{~d}$ \\
\hline $\operatorname{LSD}_{0.05}$ & 4.99 & 4.78 & 1.56 & 1.28 & 28.34 & 14.12 & 1.22 & 3.97 \\
\hline Level of Significance & $*$ & NS & $*$ & * & $*$ & $*$ & $*$ & $*$ \\
\hline SEm & 2.23 & 2.14 & 0.70 & 0.58 & 12.72 & 6.34 & 0.55 & 1.78 \\
\hline CV & $3.15 \%$ & $24.74 \%$ & $3.76 \%$ & $0.58 \%$ & $11.37 \%$ & $31.65 \%$ & $2.79 \%$ & $1.41 \%$ \\
\hline
\end{tabular}

Figures in a column having different letter (s) differ significantly at $5 \%$ level of probability according to LSD.

$\mathrm{SEm}=$ Standard Error of means; $\mathrm{CV}=$ Coefficient of Variation; NS = Non-significant; PH=Plant height, NETPH=Number of effective tillers per hill; $\mathrm{PL}=$ Panicle length; DTFPFW = Days to fifty percent flowering; NFGPP = Number of filled grains per panicle; NUGPP=Number of unfilled grains per panicle; TGW $=$ Thousand grain weight

Table 2: Effect of sowing time, variety and their combination on the yield attributes of Binadhan-17 and BRRI dhan58 at on-station

\begin{tabular}{|c|c|c|c|c|c|c|c|c|}
\hline Treatments & $\mathrm{PH}(\mathrm{cm})$ & NETPH & PL (cm) & DTFPF & NFGPP & NUGPP & TGW (g) & Duration (days) \\
\hline \multicolumn{9}{|l|}{ Sowing Time } \\
\hline $\mathrm{T}_{1}$ & $83.63 \mathrm{c}$ & 12.00 & $21.73 \mathrm{c}$ & $126.50 \mathrm{a}$ & $122.30 \mathrm{~b}$ & $31.40 \mathrm{~b}$ & 24.07 & $154.50 \mathrm{a}$ \\
\hline $\mathrm{T}_{2}$ & $91.13 \mathrm{~b}$ & 12.67 & $23.17 b$ & $122.67 \mathrm{~b}$ & $150.47 \mathrm{a}$ & $39.20 \mathrm{a}$ & 23.62 & $150.48 \mathrm{~b}$ \\
\hline $\mathrm{T}_{3}^{2}$ & $94.23 \mathrm{a}$ & 12.17 & $24.05 \mathrm{a}$ & $117.70 \mathrm{c}$ & $140.70 \mathrm{a}$ & $45.67 \mathrm{a}$ & 23.74 & $146.72 \mathrm{c}$ \\
\hline $\mathrm{LSD}_{0,05}$ & 1.28 & 1.38 & 0.78 & 1.09 & 17.304 & 7.72 & 0.87 & 2.59 \\
\hline Level of significance & * & NS & * & * & * & * & NS & * \\
\hline SEm & 0.57 & 0.62 & 0.35 & 0.49 & 7.77 & 3.47 & 0.39 & 1.16 \\
\hline \multicolumn{9}{|l|}{ Variety } \\
\hline$V_{1}$ & $86.31 \mathrm{~b}$ & 12.00 & 22.80 & $123.89 \mathrm{a}$ & 142.87 & $50.60 \mathrm{a}$ & 23.99 & $153.26 \mathrm{a}$ \\
\hline$V_{2}$ & $93.02 \mathrm{a}$ & 12.56 & 23.17 & $120.43 b$ & 132.78 & $26.91 \mathrm{~b}$ & 23.62 & $147.88 \mathrm{~b}$ \\
\hline $\mathrm{LSD}_{0.05}$ & 1.04 & 1.13 & 0.63 & 0.89 & 14.13 & 6.30 & 0.72 & 2.12 \\
\hline Level of significance & * & NS & NS & * & NS & * & NS & * \\
\hline SEm & 0.4679 & 0.5067 & 0.28 & 0.40 & 6.34 & 2.83 & 0.32 & 0.95 \\
\hline \multicolumn{9}{|l|}{ Sowing Time $\times$ Variety } \\
\hline $\mathrm{T}_{1 \times} \mathrm{V}_{1}$ & $78.86 \mathrm{e}$ & 11.67 & $22.13 \mathrm{~cd}$ & $127.33 \mathrm{a}$ & $120.87 b$ & $41.00 \mathrm{~b}$ & $24.69 a$ & $158.00 \mathrm{a}$ \\
\hline $\mathrm{T}_{1 \times} \mathrm{V}_{2}$ & $86.67 d$ & 12.33 & $21.33 d$ & $125.67 b$ & $123.73 \mathrm{~b}$ & $21.80 \mathrm{~d}$ & $23.45 b$ & $151.00 \mathrm{bc}$ \\
\hline $\mathrm{T}_{2 \times}^{1 \times} \mathrm{V}_{1}^{2}$ & $88.20 d$ & 12.33 & $22.60 \mathrm{bc}$ & $124.67 b$ & $149.60 \mathrm{a}$ & $53.53 \mathrm{a}$ & $23.90 \mathrm{ab}$ & $153.77 \mathrm{~b}$ \\
\hline $\mathrm{T}_{2 \times}^{2 \times} \mathrm{V}_{2}$ & $94.07 b$ & 13.00 & $23.73 \mathrm{a}$ & $120.67 c$ & $151.33 \mathrm{a}$ & $24.87 \mathrm{~cd}$ & $23.33 b$ & $147.20 d$ \\
\hline $\mathrm{T}_{3 \times} \mathrm{V}_{1}$ & $90.13 \mathrm{c}$ & 12.00 & $23.67 \mathrm{ab}$ & $119.67 \mathrm{C}$ & $158.13 \mathrm{a}$ & $57.27 \mathrm{a}$ & $23.40 \mathrm{~b}$ & $148.00 \mathrm{~cd}$ \\
\hline $\mathrm{T}_{3 \times} \mathrm{V}_{2}$ & $98.33 \mathrm{a}$ & 12.33 & $24.43 a$ & $116.59 \mathrm{~d}$ & $123.27 \mathrm{~b}$ & $34.07 b c$ & $24.07 a b$ & $145.43 d$ \\
\hline $\operatorname{LSD}_{0.05}$ & 1.80 & 1.96 & 1.10 & 1.55 & 24.47 & 10.92 & 1.23 & 3.67 \\
\hline Level of significance & * & NS & * & * & * & * & * & * \\
\hline SEm & 0.81 & 0.88 & 0.49 & 0.69 & 10.98 & 4.90 & 0.55 & 1.64 \\
\hline CV & $1.11 \%$ & $8.76 \%$ & $2.62 \%$ & $0.69 \%$ & $9.76 \%$ & $15.49 \%$ & $2.85 \%$ & $1.34 \%$ \\
\hline
\end{tabular}

Figures in a column having different letter (s) differ significantly at $5 \%$ level of probability according to LSD.

$\mathrm{SEm}=$ Standard Error of means; $\mathrm{CV}=$ Coefficient of Variation; NS = Non-significant; $\mathrm{PH}=$ Plant height, NETPH $=$ Number of effective tillers per hill; $\mathrm{PL}=$ Panicle length; DTFPFW =Days to fifty percent flowering; NFGPP = Number of filled grains per panicle; NUGPP=Number of unfilled grains per panicle; TGW $=$ Thousand grain weight

compared to other treatments in both the trials at on-farm and on-station (117.66 days and 116.59 days); conversely, treatment combination $\mathrm{T}_{1} \times \mathrm{V}_{1}$ had finished flowering with most time (126.78 days and 127.33 days) at farm and station.

\section{Number of Filled Grains Per Panicle}

Sowing times $T_{1}$ and $T_{2}$ produced statistically identical and most number of filled grains per panicle (151.87 and 144.70) 
followed by $\mathrm{T}_{3}(114.47)$ at farm. But at station, treatments $\mathrm{T}_{2}$ and $\mathrm{T}_{3}$ generated maximal number of filled grains (150.47 and 140.70) and statistically minimal number of filled grains per panicle was noted with planting time $\mathrm{T}_{1}(122.30)$. With varietal outcome in the farm, $\mathrm{V}_{1}$ produced more number filled grains (148.09) over $V_{2}$ (125.93) which was statistically significant. A non-significant result was obtained in the station by variety on number filled grains per panicle. United effect of sowing time and variety at farm exposed that, treatments $T_{1} \times V_{1}$ and $T_{2} \times V_{1}$ had statistically utmost number of filled grains (162.87 and 159.47). Contrary, $T_{3} \times V_{2}$ gave the lowest filled grain. In case of stational trial, treatments $\mathrm{T}_{3} \times \mathrm{V}_{1}, \mathrm{~T}_{2} \times \mathrm{V}_{2}$ and $\mathrm{T}_{2} \times \mathrm{V}_{1}$ exhibited statistically identical greater number of filled grains (158.13, 151.33 and 149.60$)$ than treatments $\mathrm{T}_{3} \times \mathrm{V}_{2}, \mathrm{~T}_{1} \times \mathrm{V}_{2}$ and $\mathrm{T}_{1} \times \mathrm{V}_{1}$ $(123.27,123.73$ and 120.87$)$

\section{Number of Unfilled Grains Per Panicle}

There was no effect of sowing time on the number of unfilled grains in the farm experiment. But; in station, ultimate number of sterile grains were observed with $\mathrm{T}_{2}(39.20)$ and $\mathrm{T}_{3}(45.67)$ which was statistically greater than $\mathrm{T}_{1}(31.40)$. Identical outcome was seen with the effect of variety on both investigations in case of grain sterility. At farm as well as on station more number of unfilled grains were noticed in $V_{1}$ (31.91 and 50.60) contrary less was noted by $V_{2}$ (17.13 and 26.91). Interaction of sowing time and variety demonstrates that, both $T_{3} \times V_{1}$ and $T_{2} \times V_{1}$ treatments generated statistically profuse number of unfilled grains at farm (36.00 and 34.67) and station (57.27 and 53.53). Significantly fewer number of sterile grains were obtained from treatments $\mathrm{T}_{2} \times \mathrm{V}_{2}(13.73)$ and $\mathrm{T}_{1} \times \mathrm{V}_{2}(15.07)$ at farm. The treatment, $\mathrm{T}_{1} \times \mathrm{V}_{2}(21.80)$ also gave little number of unfilled grains at the station trial which was statistically different compared to other treatments.

\section{Thousand Grain Weight}

Statistically similar thousand grain weight at on farm was derived from sowing time $\mathrm{T}_{1}(24.51 \mathrm{~g})$ and $\mathrm{T}_{3}(24.28 \mathrm{~g})$. $\mathrm{T}_{2}$ had the lightest seed weight $(23.50 \mathrm{~g})$ and was statistically similar to $\mathrm{T}_{3}$. Variety didn't influence one thousand seed weight. But, in the on-station trial; planting time and varietal effect didn't gave any significant result. Joint effect at farm revealed heaviest thousand grain weight from $\mathrm{T}_{1} \times \mathrm{V}_{1}(24.91 \mathrm{~g})$ and $\mathrm{T}_{3} \times \mathrm{V}_{2}(24.54 \mathrm{~g})$ treatment combination. The lightest grain weight was visible by $\mathrm{T}_{2} \times \mathrm{V}_{2}$ $(23.20 \mathrm{~g})$ which was statistically similar to $\mathrm{T}_{2} \times \mathrm{V}_{1}(23.80 \mathrm{~g}), \mathrm{T}_{3} \times \mathrm{V}_{1}$ (24.02 g) and $T_{1} \times V_{2}(24.12 \mathrm{~g})$. At station, massive thousand grain weight was seen with $\mathrm{T}_{1} \times \mathrm{V}_{1}(24.69 \mathrm{~g})$ treatment and it was statistically similar to $\mathrm{T}_{2} \times \mathrm{V}_{1}(23.90 \mathrm{~g})$ and $\mathrm{T}_{3} \times \mathrm{V}_{2}(24.07 \mathrm{~g})$. Statistically tiny and identical thousand seed weight was marked by $\mathrm{T}_{2} \times \mathrm{V}_{2}(23.33 \mathrm{~g}), \mathrm{T}_{3} \times \mathrm{V}_{1}(23.40 \mathrm{~g})$ and $\mathrm{T}_{1} \times \mathrm{V}_{2}(23.45 \mathrm{~g})$.

\section{Duration}

Maturity duration of $\mathrm{T}_{1}$ (157.00 days and 154.50 days) was the longest and $\mathrm{T}_{3}$ (152.32 days and 146.72 days) was the shortest at both on farm and stational trial respectively. Highest and lowest duration were statistically different in each location.
Here, treatment $\mathrm{T}_{2}$ gave the intermediate duration at farm (154.38 days) and at station ( 150.48 days). Variety $V_{1}$ matured earlier than $\mathrm{V}_{2}$ on both locations. At farm maximum duration was 156.92 days and minimum was 152.21 days. In station, it was 153.26 days and 147.88 days respectively. Whole effect of sowing time and variety showed that, combination $\mathrm{T}_{1} \times \mathrm{V}_{1}$ took the longest days to complete maturity days at both farm (159.33 days) and station (158.00 days). Contrary, shortest days to maturity was observed by $\mathrm{T}_{3} \times \mathrm{V}_{2}$ and $\mathrm{T}_{2} \times \mathrm{V}_{2}$ in each location. In farm it was 149.97 days and 152.00 days; and at station, it was 145.43 days and 147.20 days respectively. These results were statistically significant than the other treatment summations.

\section{Grain Yield}

Treatment $\mathrm{T}_{2}$ yielded maximum grain yield ( $\left.7.37 \mathrm{t} / \mathrm{ha}\right)$ in farm and at station $(7.31 \mathrm{t} / \mathrm{ha})$. Minimum yield was noticed when planted at $\mathrm{T}_{1}$; which was $5.93 \mathrm{t} / \mathrm{ha}$ and $6.28 \mathrm{t} / \mathrm{ha}$ at farm and station respectively (Figure 2). Under varietal influence, Binadhan-17 $\left(\mathrm{V}_{1}\right)$ produced highest yield of $6.77 \mathrm{t} / \mathrm{ha}$ and $7.03 \mathrm{t} / \mathrm{ha}$ at farm and station respectively; Contrary, this was $6.34 \mathrm{t} / \mathrm{ha}$ and $6.66 \mathrm{t} / \mathrm{ha}$ for BRRI dhan58 $\left(\mathrm{V}_{2}\right)$ (Figure 3). Summative effect of sowing time and variety produced a top yield of $7.70 \mathrm{t} / \mathrm{ha}$ at farm and 7.41 t/ha at station with combination $\mathrm{T}_{2} \times \mathrm{V}_{1}$. Contrarily, treatment $\mathrm{T}_{1} \times \mathrm{V}_{2}$ yielded $5.74 \mathrm{t} / \mathrm{ha}$ at farm and $5.94 \mathrm{t} / \mathrm{ha}$ at station (Figure 4). The highest and lowest grain yields were statistically significant.

\section{DISCUSSION}

Plant height was found to be more when sown at late $\left(\mathrm{T}_{3}\right)$ compared to earlier planting at $\mathrm{T}_{1}$ and $\mathrm{T}_{2}$. Al-Amin et al. (2019) stated a decrease in plant height with late planting. Sarker et al. (2013) concluded that, aged seedlings produce short plant height than the young seedlings. Variation with the previous findings may have occurred due to weather related factors (temperature, sun shine, relative humidity etc.) during the vegetative growth stage. Height of Binadhan-17 was low and BRRI dhan 58 was high on both locations. BINA (2017) reported that, average plant height of Binadhan- 17 was between 96 to $98 \mathrm{~cm}$ and BRRI (2012) revealed that, plant height range of BRRI dhan 58 within 100 to $105 \mathrm{~cm}$. Combined effect exhibited $\mathrm{T}_{3} \times \mathrm{V}_{2}$ as longest and $\mathrm{T}_{2} \times \mathrm{V}_{1}, \mathrm{~T}_{2} \times \mathrm{V}_{1}$ as shortest height. As discussed above, with the individual effect of sowing time and variety it is

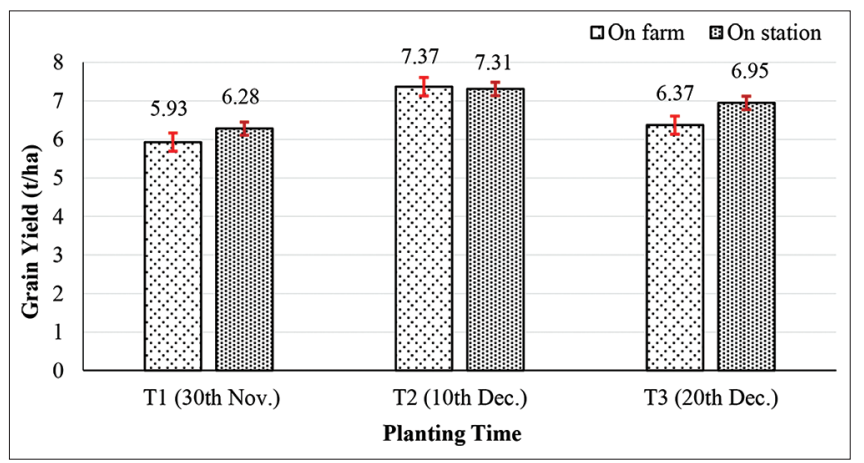

Figure 2: Influence of planting time on the grain yield of boro rice at Magura. 
much similar in interaction effect also. Safdar et al. (2008) observed that plant height of different genotype of fine rice was significantly influenced when assessed through the interaction of varieties and sowing dates. Sarkar (2014) explained that, deviation in height occur primely due to varietal genetic character.

In all cases plant height was greater in on-station than on-farm. This was probably due to intensive management practices in station like timely fertilizer application, weeding and also may be due to variation in potassium content of soil of two different locations

Sowing time, variety and their united effect was non-significant for number of effective tillers per hill. Patel et al. (2019) concluded that, aged seedlings produce fewer tillers due to the reduction of vegetative period and thereby result in poor yield. Karim et al. (2019) alluded that, mean effective tiller/hill of BRRI dhan 58 was 12.30 with varietal effect. The present result is different from the earlier findings may be due to less variation in weather during the sowing intervals and it also may have happened due to soil fertility factor(s).

On-farm, planting time and variety didn't show a role on panicle length; but their interaction revealed that, with

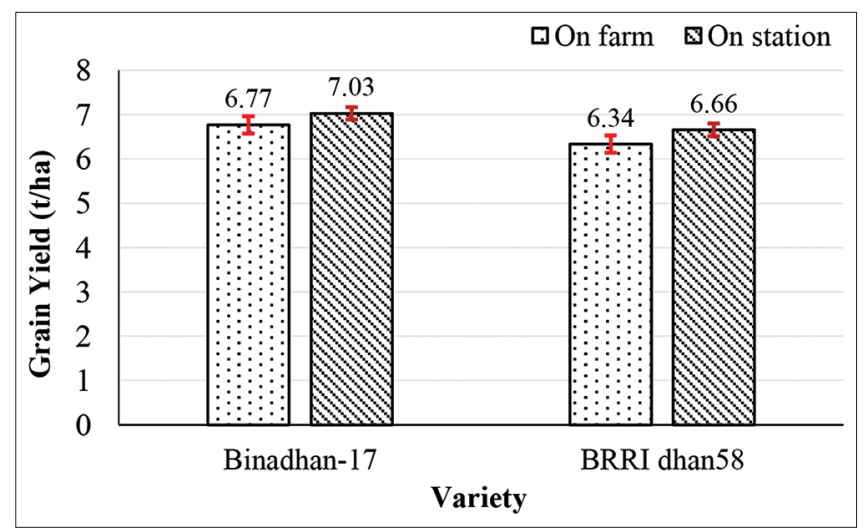

Figure 3: Grain yield of two boro rice varieties
BRRI dhan58 $\left(\mathrm{V}_{2}\right)$ when sown at $10^{\text {th }}$ December $\left(\mathrm{T}_{2}\right)$ it gave lengthiest panicle and while sown on $30^{\text {th }}$ November $\left(\mathrm{T}_{1}\right)$; demonstrated shortest panicle length. Conversely, at station longer length of panicle was noticed with late sowing at $20^{\text {th }}$ December $\left(\mathrm{T}_{3}\right)$ and shorter with early sowing on $30^{\text {th }}$ November $\left(T_{1}\right)$. Combination of effects figured that, with $V_{2}$ when sowed at $T_{3}$ and $T_{2}$ gave the highest length and when sown at $\mathrm{T}_{1}$ gave the lowest panicle length. Mean panicle length of BRRI dhan 58 was found to be between $24.12 \mathrm{~cm}$ to $25.43 \mathrm{~cm}$ under different locations (BRRI, 2018). According to BINA (2019b), panicle length of Binadhan-17 was found $22.54 \mathrm{~cm}$ to $23.31 \mathrm{~cm}$ with varietal effect and with combined effect of planting time and variety it was $22.00 \mathrm{~cm}$ to 24.08 $\mathrm{cm}$ at different location trials. Variation in panicle length was mainly due to genetic trait and planting time intervals of the varieties.

Days to fifty percent flowering varied due to differences in planting time and variety. In winter (boro season) plant growth and development remains slow for low temperature and sunshine. Therefore, plant requires more days to complete vegetative and ultimately reproductive growth, But, as time advances day length elongates and temperature rise thus, physiological processes is advanced too. Which resulted late planting early flowering (less days) and early planting late flowering (more days). BRRI dhan58 is a short duration variety and beard earlier flowering to complete its life cycle. Chopra et al. (2006) stated that days to fifty percent flowering were remarkably related with planting time. Wani et al. (2016) reported that the days taken to reach flowering and harvest varied significantly among the sowing dates. Binadhan-17's duration was much alike BRRI dhan29 in boro season. Thus, it's fifty percent flowering may have took longer to complete (Ghosh et al., 2020).

Number of filled and unfilled spikelets per panicle were greatly dominated by sowing time and varieties. Though, under normal condition rice produces $15-20 \%$ sterile grains (BRKB, 2019); but grain filling and sterility is exclusively dependent on temperature; both extreme high or low temperature is detrimental for rice anthesis and pollination. Here ten days



Figure 4: Interaction effect of planting time and variety on the grain yield of two boro rice varieties 
interval in planting time caused the wide deviation in filled and unfilled number of grains per panicle. Singh and Singh (2000) found that, low temperature at anthesis and spikelet primordial formation adversely effects grain filling. Dawadi and Chaudhary (2013) reported that extreme temperature fluctuation during flower initiation causes more number of sterile spikelets. Hasan et al., (2018) noticed changes in filled number of grains per panicle under different variety and sowing dates. Which is in conformity with the present findings.

Thousand grain weight (TGW) was unchanged with individual sowing time and varietal effect at station but their summative effect showed a variable result. Conversely, at farm combined effects gave a closer result on TGW. Grain weight is mainly a genetic character of the variety which may vary due to weather, soil nutrition factor(s) and stress condition(s). Chowhan et al., (2017) found differences in grain weight at different rice varieties following same treatments. BINA (2019b) reported that, with varietal effect thousand grain weight range is $22.84 \mathrm{~g}$ to 23.76 g; with sowing time between January 24 to February 13 mean grain weight was found $23.58 \mathrm{~g}$ to $24.49 \mathrm{~g}$ and their interaction resulted a range of $22.38 \mathrm{~g}$ to $24.07 \mathrm{~g}$ incase of Binadhan-17. BRRI (2018) concluded, average thousand grain weight of BRRI dhan 58 was $21.44 \mathrm{~g}$ to $21.56 \mathrm{~g}$ at boro season under various nutrient source treatment. So, the present outcomes are more or less supported by the earlier findings.

Sowing time, varieties and their interaction played a significant role on the growth duration and grain yield of boro rice. It was noted that, within the advancement of time and planting maturity days were reduced both on farm and station but, grain yield increased when planted at $10^{\text {th }}$ December $\left(\mathrm{T}_{2}\right)$ compared to $30^{\text {th }}$ November $\left(\mathrm{T}_{1}\right)$ and $20^{\text {th }}$ December $\left(\mathrm{T}_{3}\right)$. It's an indication that, sowing of seeds on $10^{\text {th }}$ December $\left(\mathrm{T}_{2}\right)$ is a major factor for gaining optimal yield. Contrary, Binadhan-17 $\left(\mathrm{V}_{1}\right)$ yielded more than BRRI dhan 58 in both locations but duration was more. BRRI (2019) mentioned that, mean yield and duration of BRRI dhan 58 was $6.75 \mathrm{t} /$ ha and 150 days at multi locational trials. Nath et al., (2018) observed a yield of $8.74 \mathrm{t} / \mathrm{h}$ a following IPNS. Binadhan-17 being a short duration aman variety it's maturity duration and yield was higher in boro season. BINA (2019b) alluded that, delayed planting of Binadhan-17 resulted significant shortening of life cycle as well as declination of grain yield. Ghosh et al., (2015) reported variation in maturity influenced by different cultivars. Ehsanullah et al., (2014) found, late planting of rice results in poor growth than early planting; therefore, fluctuation in temperature also affects rice growth period.

\section{CONCLUSION}

From the above variation in sowing times. It can be concluded that, sowing at $10^{\text {th }}$ December can be fruitful for gaining optimum yield of Binadhan-17 at Magura region. As weather factor(s) is an important criterion for growth, duration and yield of every crop; this result may alter with differences in weather and agro-ecological zones of Bangladesh. Because of extensive popularity of this variety; farmers are suggested to cultivate this high yielding variety in the boro season instead of aman by adjusting the sowing time as above for getting insect and disease free production with potential yield.

\section{ACKNOWLEDGMENTS}

Authors are thankful to Md. Abu Sayeed, ASO of BINA Substation, Magura for his toiled effort and sincere assistance throughout the entire research work. The authors also express their gratitude to Mrinal Kumar Shil, ASM Mushfiqur Rahman, staffs and labors of the sub-station for data collection, doing required management practices in the field and relevant works needed in the experiment. We are obliged to the Bangladesh Institute of Nuclear Agriculture for providing necessary supports to carry out this field trial.

\section{DISCLAIMER}

Partial portion of this experimental result was presented (as abstract) in the International Conference on Environmental, Agriculture and Rural Development (EARD-2020). October 17-18, 2020, India.

\section{CONFLICT OF INTEREST}

Authors do not have any conflict of interests to declare.

\section{REFERENCES}

Ahmmed, S., Jahiruddin, M., Razia, S., Begum, R. A., Biswas, J. C. Rahman, A. S. M. M., Ali, M. M., Islam, K. M. S., Hossain, M. M., Gani, M. N., Hossain, G. M. A., \& Satter, M. A. (2018). Fertilizer Recommendation Guide-2018. Bangladesh Agricultural Research Council (BARC), Farmgate, Dhaka-1215. 223p.

Al-Amin, M., Nasrin, S., Mabud, A. K. M., Sani, M. N. (2019). Effect of planting date on the performance of high yield potential varieties of rice in Bangladesh. Asian Journal of Advances in Agricultural Research, 9(4), 1-11. https://doi.org/10.9734/ajaar/2019/v9i430016

BBS (Bangladesh Bureau of Statistics). (2020). Yearbook of Agricultural Statistics-2019. 31st Series, Planning Division, Ministry of Planning, Dhaka, Bangladesh. pp. 1-66. Retrieved from http:// bbs.portal.gov.bd/sites/default/files/files/bbs.portal.gov.bd/ page/1b1eb81799325_4354_a756_3d18412203e2/2020-10-06-0958-453f7e0a42348e05f0999979870-ec07b.pdf

Bhowmik, S. K., Sarkar, M. A. R., \& Zaman, F. (2012). Effect of spacing and number of seedlings per hill on the performance of Aus rice cV. NERICA 1 under dry direct seeded rice (DDSR) system of cultivation. Journal of the Bangladesh Agricultural University, 10(2), 191-195. https://doi.org/10.3329/jbau.v10i2.14681

BINA (Bangladesh Institute of Nuclear Agriculture). (2017). Binadhan-17 Leaflet (/n Bengali). Retrieved from https://bina.portal.gov.bd/sites/ default/files/files/bina.portal.gov.bd/page/e598357f_0ebb_46a4 ad26_3b0bbfc4f815/binadhan17.pdf

BINA (Bangladesh Institute of Nuclear Agriculture). (2019a). Weather status HOBOlink- Magura. (cited 2020 June 11). Retrieved from https://www. hobolink.com/p/b82909d639dbdd5f400a7f2a5b54b5a0

BINA (Bangladesh Institute of Nuclear Agriculture). (2019b). Annual Report of Bangladesh Institute of Nuclear Agriculture 2018-19. Mymensingh-2202, Bangladesh. pp. 400-404.

Boyer, J. S. (1982). Plant productivity and environment. Science, 218(4571), 443-448. https://doi.org/10.1126/science.218.4571.443

BRKB (Bangladesh Rice Knowledge Bank). (2019). Problems and solution of rice production. 23p. (Accessed 03 September 2019) Retrieved from http://knowledgebank-brri.org/Publications/problems-andsolutions.pdf

BRRI (Bangladesh Rice Research Institute). (2012). BRRI dhan58 leaflet 
(/n Benga/i). Retrieved from http://knowledgebank-brri.org/Rice Production_Training_Manual/Day_1/Module_2/Boro/BRRIdhan58.pdf

BRRI (Bangladesh Rice Research Institute). (2018). Annual Report of Bangladesh Rice Research Institute 2017-18. BRRI, Gazipur 1701, Bangladesh. pp. 274-321

BRRI (Bangladesh Rice Research Institute). (2019). Annual Report of Bangladesh Rice Research Institute 2018-2019. BRRI, Gazipur 1701. Bangladesh. pp. 113-260.

Chopra, N. K., Chopra, N., Yadav, R. N., Nagar, K. C. (2006). Effect of transplanting dates on seed yield and quality of paddy cv. Pusa-44. Seed Research, 34(2), 218-220

Chowhan, S., Gupta, R., Islam, M. M., Begum, S. N. (2018). Evaluation of NERICA rice mutant in jhum cultivation. International Journal of Agronomy and Agricultural Research, 12(2), 24-31.

Chowhan, S., Haider, M. R., Hasan, A. F. M. F., Hoque, M. I., Kamruzzaman, M., Gupta, R. (2017). Comparative on farm performance of five modern rice varieties with two local cultivars. Journal of Bioscience and Agriculture Research, 13(01), 1074-1086. https://doi.org/10.18801/ jbar.130117.131

Chowhan, S., Hoque, M. I., Ghosh, S. R., Islam, M., \& Akter, M. B. (2019). Effect of variety and seedling number on the growth and yield of boro rice in Bangladesh. Journal of Experimental Agriculture International, 41(6), 1-15. https://doi.org/10.9734/jeai/2019/v41i630436

Dawadi, K., Chaudhary, N. (2013). Effect of sowing dates and varities on yield and yield attributes of direct seeded rice in Chitwan condition. Journal of Agriculture and Environment, 14, 121-130. https://doi. org/10.3126/aej.v14i0.19792

Ehsanullah, Anjum, S. A., Ashraf, U., Rafiq, H., Tanveer, M., Khan, I. (2014). Effect of sowing dates and weed control methods on weed infestation, growth and yield of direct-seeded rice. The Philippine Agricultural Scientist, 97, 307-312.

FAOSTAT (Statistics Division, Food and Agriculture Organization of the United Nations). (2020). Crops-Rice (cited 2020 Nov 29). Retrieved from http://www.fao.org/faostat/en/\#data/QC

Ghosh, S. R., Chowhan, S., Mondal, M. T. R., Roy, D. C., Ferdous, H. M., Sultana, M. R., Ahmmed, F., Ali, M. I., Hoque, M. I. (2020) Influence of variety and sowing dates on the yield and maturity of boro rice. The 7th International Conference on Agriculture 2020 (p. 35). ISBN: 978-955-3605-58-0

Ghosh, U. K., Khan, A. R., Karim, M. A. (2015). Growth performance of aus rice varieties under rainfed condition. International Journal of Advanced Multidisciplinary Research, 2(11), 29-35.

Gomez, K. A., \& Gomez, A. A. (1984). Statistical Procedures for Agricultural Research. $2^{\text {nd }}$ Edition. John Wiley and Sons. New York. 680p.

Hasan, A. K., Islam, S. S., Karim, M. R., Islam, M. A., Rahman, M. A. (2018). Influence of variety and sowing dates on the yield and yield attributes of boro season rice in aerobic condition. Asian Journal of Science and Technology, 09(2), 7570-7575.

Karim, M., Kashem, M. A., Huda, A., Aziz, M. A., Goswami, B. K. (2019). Effect of different doses of urea on the yield of boro rice varieties in haor areas of Bangladesh. Asian Plant Research Journal, 3(2), 1-9. https://doi.org/10.9734/aprj/2019/v3i230061

Khatun, S., Mondal, M. M. A., Khalil, M. I., Roknuzzaman, M., Mollah, M. M. I. (2020). Growth and yield performance of six aman rice varieties of bangladesh. Asian Research Journal of Agriculture, 12(2), 1-7. https://doi.org/10.9734/arja/2020/v12i230077

Nath, A., Kashem, M. A., Ali, S. (2018). Growth and yield performance of boro rice (BRRI dhan58) under different fertilizer and agronomic management in wetland. International Journal of Agricultural Research, 13, 53-57. https://doi.org/10.3923/ijar.2018.53.57

Patel, A. R., Patel, M. L., Patel, R. K., Mote, B. M. (2019). Effect of different sowing date on phenology, growth and yield of rice-A Review. Plant Archives, 19(1), 12-16

Paul, S. K., Roy, B., Hasan, A. K., Sarkar, M. A. R. (2017). Yield and yield components of short duration transplant aus rice (cv. Parija) as influenced by plant spacing and nitrogen level. Fundamental and Applied Agriculture, 2(2), 233-236.

Safdar, M. E., Sarwar, A.A.S.M.G., Awan, T. H. (2008). Effect of transplanting dates on paddy yield of fine grain rice genotypes. Pakistan Journal of Botany, 40(6), 2403-2411.

Sarkar, S. C. (2014). Performance of five selected hybrid rice varieties in aman season. MSc Thesis in Agricultural Botany, Sher-e-Bangla Agricultural University, Dhaka. pp. 25-46.

Sarker, M. H., Rahman, M. M., Yusouf, M. N., Kabir, M. M. M., Alam, M. K. (2013). Effect of age of seedlings on growth and yield of two modern rice varieties during boro season. International Journal of Biological Research, 15(6), 40-50.

Singh, V.P., Singh, V. K. (2000). Effect of sowing date and nitrogen level on productivity of spring sown rice (Oryza sativa) varieties in low hills of Uttaranchal. Indian Journal of Agronomy, 45(3), 560-563.

Sofield, K., Evans, L. T., Cook, M. G., \& Wardlaw, F. (1977). Factors influencing the rate and duration of grain filling in wheat. Australian Journal of Plant Physiology, 4, 785-797. https://doi.org/10.1071/ PP9770785

Statistix- Data analysis software for researchers (Version 10.0). (2020). Analytical Software, 2105 Miller Landing Rd, Tallahassee Florida 32312, USA. Retrieved from https://www.statistix.com/

Wani, S. A., Qayoom, S., Bhat, M. A., Lone, B. A., Nazir, A. (2016). Influence of sowing dates and nitrogen levels on growth yield and quality of scented rice cv. Pusa Sugandha-3 in Kashmir valley. Journal of Applied and Natural Science, 8(3), 1704-1709. 